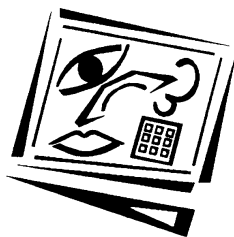

\title{
Postgraduate students' knowledge construction during asynchronous computer conferences in a blended learning environment: A Malaysian experience
}

\author{
Hong Kian-Sam and Julia Ai Cheng Lee \\ Universiti Malaysia Sarawak
}

\begin{abstract}
Blended learning, using e-learning tools to supplement existing on campus learning, often incorporates asynchronous computer conferencing as a means of augmenting knowledge construction among students. This case study reports findings about levels of knowledge construction amongst adult postgraduate students in six asynchronous computer conferences in a blended learning environment. The aim is to document and understand the kinds of task related postings in asynchronous computer conferencing that foster knowledge construction. The tool for analysis is an adaptation of the model by Veerman and Veldhuis-Diermanse (2001). Data were collected from Quickplace, the e-learning system at Universiti Malaysia Sarawak, with 22 adult postgraduate students enrolled in the Masters of Science in Human Resource Development who were attending a 14-week course on Cognition and Learning. The results showed that the students were active in constructing knowledge but limited to seeking and giving opinions among peers and knowledge telling. The prevalence of low level knowledge construction points to the need for the e-learning facilitator to encourage the students to go beyond regurgitating facts of what they have learned. More guidance should be given to the students to refrain from mere knowledge telling. Results suggest that there are blended learning benefits for these students as they are given improved opportunities to learn outside the classroom.
\end{abstract}

\section{Introduction}

Current practices in institutions of higher learning indicate that the use of information and communication technologies (ICTs), in particular e-learning, is increasing at a great pace (Ewing \& Miller, 2002; Hmelo-Silver, 2003; Hong, Lee \& Liau, 2005; Schellens \& Valcke, 2005; Woo \& Reeves, 2007; Young \& Norgard, 2006). E-learning is defined as the use of Internet technologies to deliver a combination of learning contents and instructional methods to enhance a learner's knowledge and performance (Rovai, 2004). E-learning systems such as WebCT and Blackboard are popular among educators and can integrate a variety of functions. For example, these systems can incorporate instructional materials using audio, video and text, email, online conferencing, forums, quizzes and assignments and the Web. Instructional delivery 
and communication between instructors and students can be conducted synchronously (at the same time) or asynchronously (at different times), offering a variety of instructional aids, communication methods and flexibilities in terms of place and time of instruction (Hong, 2002).

Many educational institutions have invested in e-learning. For example, in the United Kingdom, the Higher Education Funding Council for England (HEFCE) has published its e-learning strategy, which sets out strategies and implementation plans for supporting e-learning in higher education institutions. HEFCE was reported to be allocating 33 million UK pounds in capital funding for e-learning (HEFCE, 2005).

In e-learning environments, one of the most common types of communication is asynchronous conferencing. In asynchronous conferencing, learners usually interact with each other at different times via text messages allowing them more time to reflect, think and search for additional information when compared with synchronous conferencing (Frank, Kurtz, \& Levin, 2002; Hong, 2002; Jonassen, 2001; Woo \& Reeves, 2007, Wu \& Hiltz, 2004; Young \& Norgard, 2006). Within the scope of adult and postgraduate learning, e-learning and asynchronous conferencing have gained popularity and acceptance because the time to travel physically to and from institutions of learning is now compensated by online accessibility and hence offers much convenience that extends beyond the walls of the physical classroom (King, 2002).

Furthermore, Shellens and Valcke $(2005,2006)$ in their study on the existence of knowledge construction in asynchronous conferencing found that collaborative online discussion groups were very task oriented and that high phases of knowledge construction were exhibited. Other studies such as Pena-Shaff and Nicholls (2004) have shown that students in asynchronous conferencing were engaged in knowledge construction processes and produced more reflective monologues. However, in a study among postgraduate students in an e-learning statistics course at a tertiary institution in Malaysia, Hong (2002) reported that although there was some evidence of critical thinking during the asynchronous conferencing, the discussions were generally at low levels of knowledge construction.

\section{Blended learning environments}

Blended learning refers to the hybrid of traditional face to face and e-learning, where the e-learning is meant to enhance students' learning by taking advantage of the anytime, anywhere features of e-learning technologies (Egan, Jefferies \& Johal, 2006; Ginns \& Ellis, 2007; Oliver \& Trigwell, 2005; Reasons, Valadares \& Slavkin, 2005; Wu \& Hiltz, 2004). There are various versions of blended learning where some universities may have an initial face to face meeting, weekly online assessments and online discussions, and a final face to face meeting with an examination (Rovai, 2004). Other universities reduce the face to face sessions to one-third of the time usually needed to meet, for example, a one-hour face to face session instead of a three-hour session. 
In the case of Universiti Malaysia Sarawak, the use of e-learning is meant to act as a complementary learning support system, while not reducing the duration of face to face sessions. It is the University's policy to offer blended learning rather than distance learning education at the undergraduate and graduate levels of learning (Hong et al., 2005; Universiti Malaysia Sarawak, 2002). In Unimas, the face to face sessions run as normal and students meet their course facilitator for three hours per week for a threecredit course. The e-learning facility is meant to allow the students to participate in asynchronous conferences, to ask questions, and to construct meanings of the domain knowledge acquired inside and outside class.

\section{Purposes of the study}

With the increasing use of blended learning and asynchronous computer conferences, educators should assess the quality of interactions and learning that take place in this e-learning environment. According to Hmelo-Silver (2003), Walker (2005) and Woo and Reeves (2007), documenting collaborative knowledge construction is critical for research in asynchronous conferencing and e-learning environments. Thus, the goals of this study were to document the types of knowledge that were constructed during the asynchronous conferencing and evaluate the quality of knowledge construction taking place in a blended learning environment for a postgraduate course at a Malaysian tertiary institution.

\section{Review of related literature}

The benefits of e-learning, blended learning, and asynchronous computer conferencing are well documented in the literature (Frey, Millie \& Alman, 2006). Asynchronous computer conferences are convenient because they are not time or place dependent. Not only can students respond at their own pace, they all have an equal opportunity to express themselves (Pallof \& Pratt, 2002; Frey et al., 2006). Asynchronous computer conferencing provides a permanent record (Meyer, 2004) of interaction that is easy to archive and search. In addition, asynchronous computer conferences are collaborative, which allows for a social construction of knowledge (Walker, 2005). Positive learning outcomes are also attributed to the thoughtful reflection required in composition of computer conference postings (Allan, 2004). Furthermore, writing-to-learn literature describes writing as a way to reflect, analyse, and communicate important ideas and concepts, as Elbow (1994, p. 4) stated, "Students understand and retain course material much better when they write copiously about it." According to Walker (2005), common writing assignments such as answering and responding to other learners' discussion questions, analysing case studies, writing reports, research papers, project summaries and collaborative written assignments, such as developing team reports on specific topics, group answers to discussion questions, debates and critiques of arguments can enhance knowledge construction.

Student reflection is often prompted by questions that serve one of two functions they are either centering (questions that promote convergent thought) or expanding 
(questions that promote divergent thought) (Hunkins, 1972). Blanchette (2001) found that asynchronous computer conferencing allows for higher levels of cognitive questions that encourage critical thinking. Learners have more time process questions and develop responses, and the learner's cognitive level of response often matches the cognitive level of the questions asked. Muilenburg and Berge (2000) agreed, reporting that the level of student thinking is directly proportional to the level of questions asked.

The benefits of asynchronous computer conferencing have led several researchers to further explore student interaction and develop models and tools for asynchronous computer conferencing analysis. There are several types of analysis, including frequency of postings and content analysis. Content analysis studies have generally been qualitative and explore issues such as problem solving or critical thinking (Garrison, Anderson, \& Archer, 2001; Meyer, 2004; Rourke \& Anderson, 2004; Veerman \& Veldhuis-Diermanse, 2001). Quantitative studies focus on measures such as frequency of postings, which may include the number of threads per conference, the number of postings per thread, or the number of instructor postings per thread (Mazzolini \& Maddison, 2003; Monroe, 2003).

In view of the increasing use of asynchronous conferencing in blended learning, there is a need for analysis tools that review the process of knowledge development within these online discussions. Veerman and Veldhuis-Diermanse (2001) worked on a categorising model of knowledge construction based on social constructivist principles (Schellens \& Valcke, 2006), and having two major categories: task related and non-task related discussions. There were four categories of non-task discussions. The four categories with examples of the posting are: (a) Planning: "Is it OK to discuss the arguments first"?; (b) Technical: "Do you know how to change the diagram window?"; (c) Social: "Smart thinking"; and (d) Nonsense: "What about a swim this afternoon?" (Veerman \& Veldhuis-Diermanse, 2001). The task related discussions, on the other hand, consisted of three major categories. The three categories with examples of the posting are: (a) New idea: "Interaction means responding to each other"; (b) Explanation: "I mean that you integrate information of someone else in your reply"; and (c) Evaluation: "I don't think that's a suitable description because interaction means also interaction with computers or materials, see Laurillard's definition" (Veerman \& Veldhuis-Diermanse, 2001).

Veerman and Veldhuis-Diermanse (2001) further elaborated that a New idea can be described as a task related posting, focused on relevant content that is not mentioned before. An Explanation is a posting in which information is refined or elaborated that was clearly stated before, but elsewhere in the discussion. An Evaluation message is more than a "Yes, what a good idea" message and often involves reasoning processes or justifications.

Veerman and Veldhuis-Diermanse (2001) used their model successfully for analysing knowledge construction in four studies with different groups of undergraduate 
students at Utrecht University and Wageningen University in the Netherlands, using computer mediated communications (CMC) systems. They found that asynchronous CMC can provide students with more options to think and reflect on information, to organise and keep track of discussions, and to engage in large group discussions. Schellens and Valcke (2005) have also used Veerman and Veldhuis-Diermanse's model to investigate whether asynchronous discussion groups can enhance knowledge construction. Their study showed that the interaction of discussions amongst learners was very task oriented and reflected higher phases of knowledge construction.

\section{Methods}

A case study method was used to investigate the type of knowledge constructed and the quality of discussions that took place in the asynchronous computer conferencing, because neither variables nor potential causes of behaviour were manipulated.

\section{Participants}

The participants in this study were 22 adult students enrolled in the Masters of Science in Human Resource Development program, at the Faculty of Cognitive Sciences and Human Development, Unimas, taking the 14-weeks course, KMK6063 Cognition and Learning in September 2006. All the participants were adults who worked during the day at various public and private companies. Many of them were teachers, one an officer at the state library, and some were full time students. Only two of the participants had limited access to computers and one of them did not participate in the asynchronous computer conferencing.

\section{Description of the course}

The course KMK6063 Cognition and Learning was designed to equip the adult students with the knowledge, skills and attitudes required to understand, appreciate, and diagnose how humans learn. The students were given a set of weekly readings and they were encouraged to participate in the online course discussion as often as possible. As a three-credit unit course, the face to face activities of the course consisted of three hours of lectures, and the time spent online was unlimited. A maximum of five points were allocated to students who participated actively in the asynchronous computer conferences in the blended learning environment. Throughout the 14 weeks, there were six asynchronous computer conferences, which were initiated by the second author, the course and e-learning facilitator. The e-learning facilitator's function was to generate meaningful online discourse about the topics learned in class, to stimulate and monitor the discussions, and also to explain misconceptions about certain concepts.

\section{Features of the course}

The e-learning component of the course, illustrated in Figure 1, was meant to play a complementary role to the face to face learning sessions. The software, Quickplace, was 
used to support the e-learning course and asynchronous computer conferences. A welcome note and information on the purposes of the e-learning course page were presented to orientate the students on e-learning.

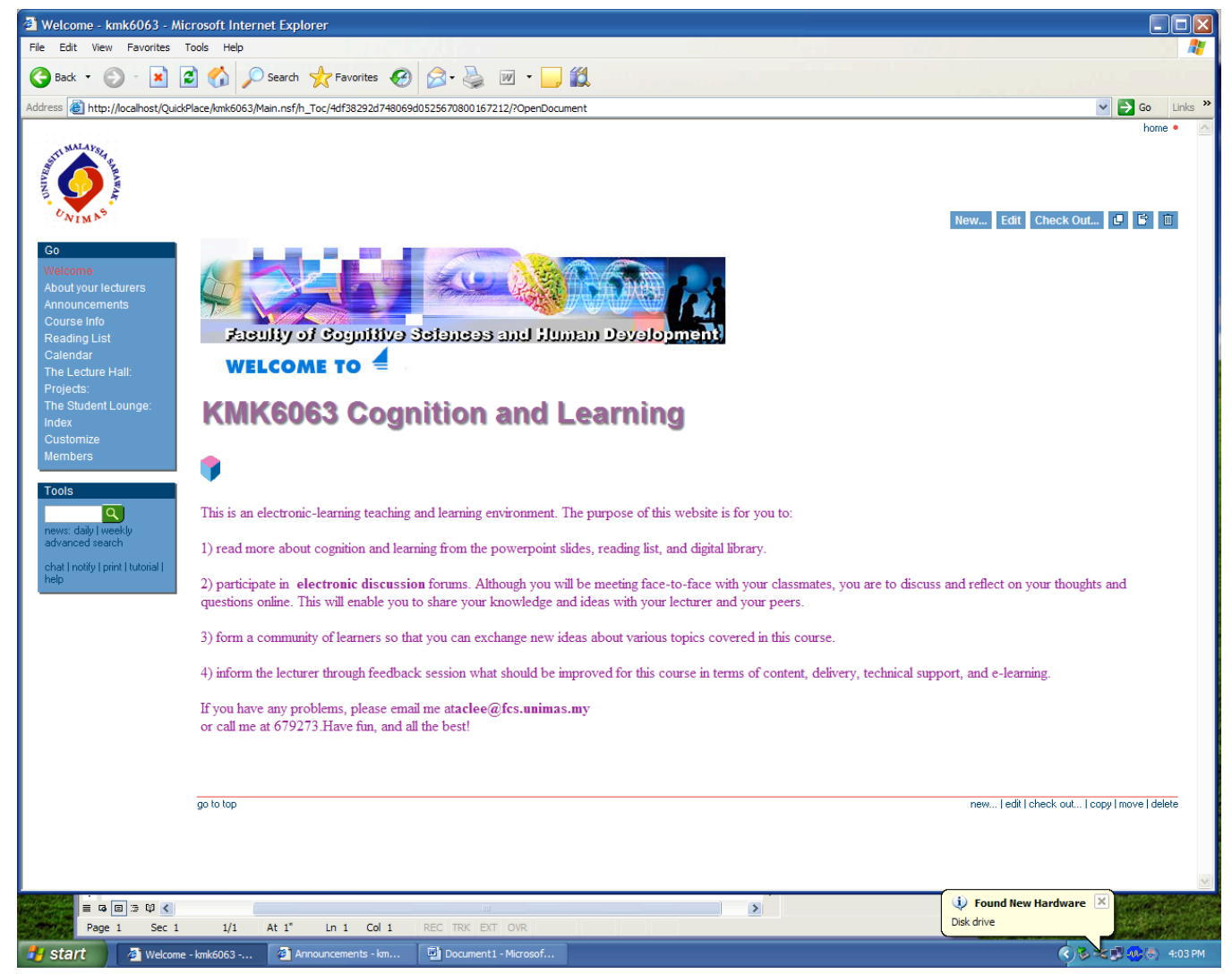

Figure 1: E-learning component of the course using Quickplace

\section{Topics for the asynchronous computer conferences}

Two examples of facilitator-led discussion topics in the asynchronous computer conferences, with some guiding questions of the convergent and divergent types (Hunkins, 1972) were:

1. Dear students, we have watched a video on Brain Learning on December 17, 2004 but we didn't have enough time to discuss in class. I suggest that we continue our learning process in the virtual space. Please write out three main points on how this particular video relates to your profession e.g.: teacher, employee of the inland 
revenue, Bernas, Pustaka Negeri Sarawak, Everise etc. Try to focus your answers on the following questions:

a. What is your impression of the video? (e.g.: if you like what you saw, tell us why. If you felt that the video was not interesting, give us your reason.)

b. What are the three important features you noticed from the video? Why do you notice them?

c. How does this video relate to your profession? How would you apply what you have learned at your place of work?

Post your responses. Comment and discuss on your friends' responses and queries. - Julia

2. You will find in the attachment, three articles and one PowerPoint notes. Print out the three articles. Ask three most salient questions about the articles and discuss each others' questions. I have allocated marks for the online discussion - Julia

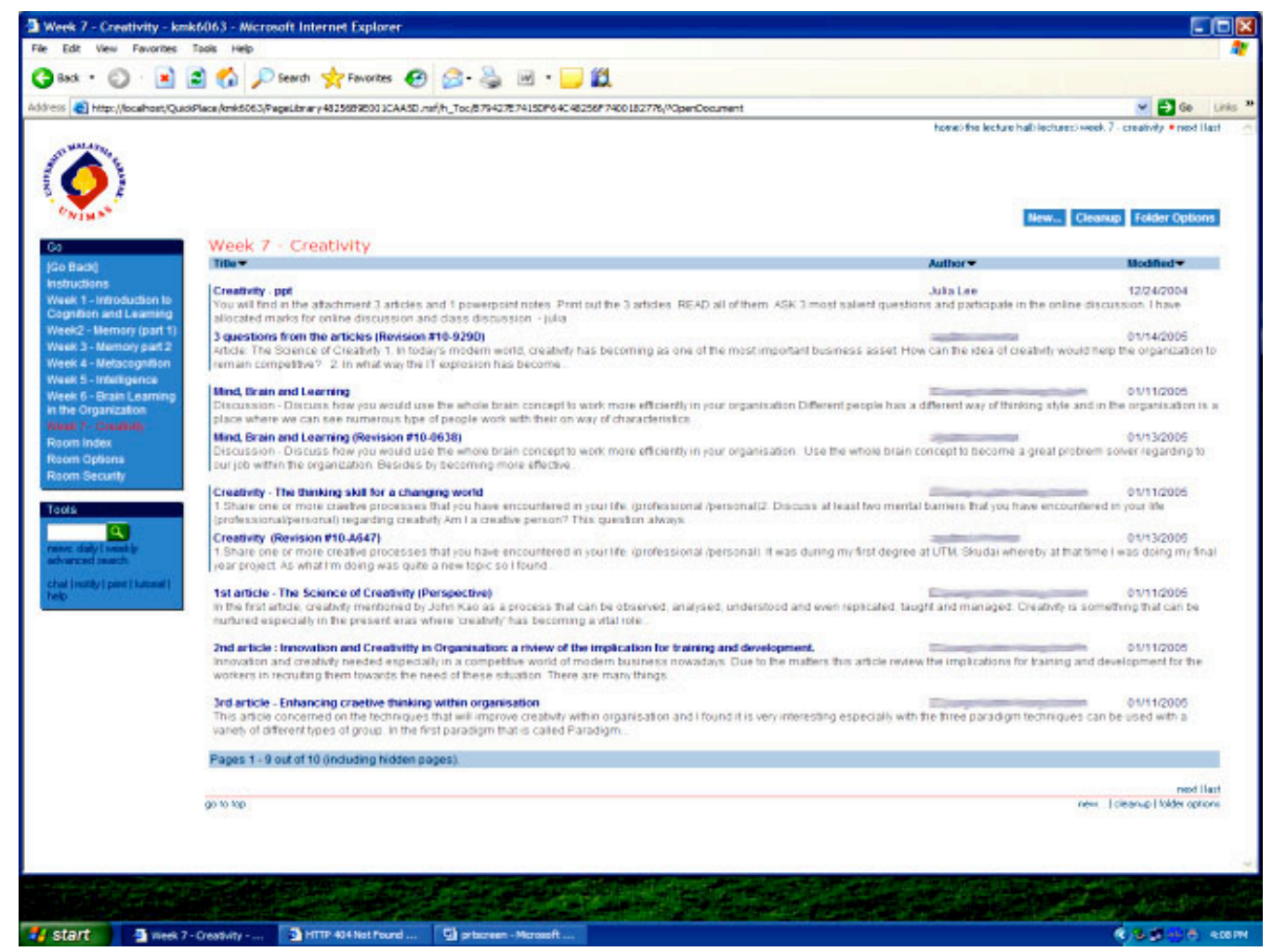

Figure 2: Example of a computer conference session 
The discussions in the asynchronous computer conferences were in a threaded format making it easier for the students to follow the ongoing discussions. Students could click on any discussion thread and simply follow any discussion posted by their peers or the topics posted by the course facilitator as shown in Figure 2.

\section{Data analysis}

Initially, students' participation and the number of discussion postings were analysed using frequency measures. Content analysis was then used to analyse and describe the knowledge construction episodes in the asynchronous computer conferences. In this study, the researchers defined each meaningful sentence in the asynchronous computer conference posting as a unit of analysis. The sentences were smaller chunks of information that usually contain only one main piece of salient information (Gee, 1999). Each sentence was considered an independent discourse but at the same time dependent on the context of a bigger meaningful issue being discussed. Thus a computer conference posting by one student could comprise of a few units of analysis as shown in Table 1.

Table 1: Example of a computer conference posting and its units of analyses

\begin{tabular}{|l|c|c|}
\hline \multicolumn{1}{|c|}{ Example of a computer conference posting } & $\begin{array}{c}\text { Unit of } \\
\text { analysis }\end{array}$ & \multicolumn{1}{|c|}{ Code scheme } \\
\hline $\begin{array}{l}\text { We cannot deny that in this modern world of technology, a lot of } \\
\text { electronic devices have been creatively designed to make life easier } \\
\text { such as hand phones... even more perfect than a human brain } \\
\text { because it never fails to remember. My observation is human } \\
\text { beings like you and me has been too dependent on electronic } \\
\text { devices for remembering names,... lots of memory }\end{array}$ & 1 & Give opinion \\
\hline$\ldots$ the human brain is never overloaded. & 2 & $\begin{array}{l}\text { Incorrect } \\
\text { knowledge telling }\end{array}$ \\
\hline $\begin{array}{l}\text { Just imagine if one day such devices just suddenly disappear from } \\
\text { the earth, what are we going to do? }\end{array}$ & 3 & Ask for opinion \\
\hline $\begin{array}{l}\text { For something we don't like, we are also interested to remember } \\
\text { what we don't like! }\end{array}$ & 4 & Give opinion \\
\hline
\end{tabular}

The analysis tool for the content analysis of the computer conferences postings was adapted from the model by Veerman and Veldhuis-Diermanse (2001). This tool was applicable to this study because of Veerman and Veldhuis-Diermanse's focus on the examination of collaborative learning as a process of knowledge construction, which is the main focus of this paper. The original categories for analyses are available in Veerman and Veldhuis-Diermanse (2001). The modified categories for analyses with examples are shown in Table 2. The major categories were non-task related discussion, task related discussion, and facilitator discussion. The facilitator category is an addendum to the Veerman and Veldhuis-Diermanse's (2001) model, which was not included in the original coding scheme. Modifications were also made to expand the task related category, from three sub-categories (new idea, explanation and evaluation), to seven sub-categories (ask for opinion/ encourage participation, give opinion, with examples, 
knowledge telling, inaccurate knowledge telling, new idea, evaluation). Based on the definitions for the various sub-categories in the task related category, and with reference to the Revised Bloom's Taxonomy (Smythe \& Halonen, undated), the subcategories of with examples, new idea and evaluation depict higher levels of knowledge construction similar to the analyse, evaluate and create in the Revised Bloom's Taxonomy. On the other hand, the other sub-categories in the task related category are considered to be low level knowledge construction.

Table 2: Categorising asynchronous computer conference postings

\begin{tabular}{|c|c|c|c|c|}
\hline & Message & Definition & Example & $\begin{array}{l}\text { Knowledge } \\
\text { construction }\end{array}$ \\
\hline \begin{tabular}{|c|} 
Non- \\
task \\
related
\end{tabular} & Planning & $\begin{array}{l}\text { Statement related to the } \\
\text { procedure of team work/ } \\
\text { how the discussion should } \\
\text { be conducted. }\end{array}$ & $\begin{array}{l}\text { Shall we talk about the most } \\
\text { important issues first? }\end{array}$ & No \\
\hline & Technical & $\begin{array}{l}\text { Statements related to the } \\
\text { technical use of the e- } \\
\text { learning software. }\end{array}$ & $\begin{array}{l}\text { You can download any of the } \\
\text { files below by dragging them } \\
\text { to your Windows desktop. To } \\
\text { open a file for reading, } \\
\text { double click it. }\end{array}$ & No \\
\hline & Social & $\begin{array}{l}\text { Statements that serve to } \\
\text { foster friendship/ } \\
\text { camaraderie. }\end{array}$ & Glad to hear from you all. & No \\
\hline & Nonsense & $\begin{array}{l}\text { Statements that are entirely } \\
\text { irrelevant to the discussion } \\
\text { proper. }\end{array}$ & I see birds flying in the book. & No \\
\hline \begin{tabular}{|c|} 
Task \\
related
\end{tabular} & $\begin{array}{l}\text { Ask for } \\
\text { opinion or } \\
\text { encourage } \\
\text { participation }\end{array}$ & $\begin{array}{l}\text { Asking a question but not } \\
\text { connecting it to other } \\
\text { threads or encouraging } \\
\text { other members to } \\
\text { participate. }\end{array}$ & $\begin{array}{l}\text { Any suggestion to improve } \\
\text { my marketing presentation? }\end{array}$ & Yes \\
\hline & $\begin{array}{l}\text { Knowledge } \\
\text { telling }\end{array}$ & $\begin{array}{l}\text { Statements based on } \\
\text { regurgitated facts from the } \\
\text { class or from readings } \\
\text { without any connection to } \\
\text { personal knowledge. }\end{array}$ & $\begin{array}{l}\text { It was stated in the article } \\
\text { that if you have an interest in } \\
\text { remembering well, you will } \\
\text { be able to remember. }\end{array}$ & Yes \\
\hline & $\begin{array}{l}\text { Inaccurate } \\
\text { knowledge } \\
\text { telling }\end{array}$ & $\begin{array}{l}\text { Statements that are } \\
\text { inaccurate and contain } \\
\text { wrong facts. }\end{array}$ & $\begin{array}{l}\ldots \text { the human brain is never } \\
\text { overloaded. }\end{array}$ & Yes \\
\hline & Give opinion & $\begin{array}{l}\text { Statements depicting parti- } \\
\text { cipants' personal views, an } \\
\text { interpretation or inference } \\
\text { from the discussion. }\end{array}$ & People are different. & Yes \\
\hline & $\begin{array}{l}\text { With } \\
\text { examples }\end{array}$ & $\begin{array}{l}\text { Statements accompanied by } \\
\text { supporting examples, } \\
\text { concrete ideas, or } \\
\text { application of knowledge. }\end{array}$ & $\begin{array}{l}\text { Through visualised... } \\
\text { organise the lessons in a } \\
\text { limited principles and } \\
\text { connecting content under } \\
\text { common labels. }\end{array}$ & Yes \\
\hline
\end{tabular}




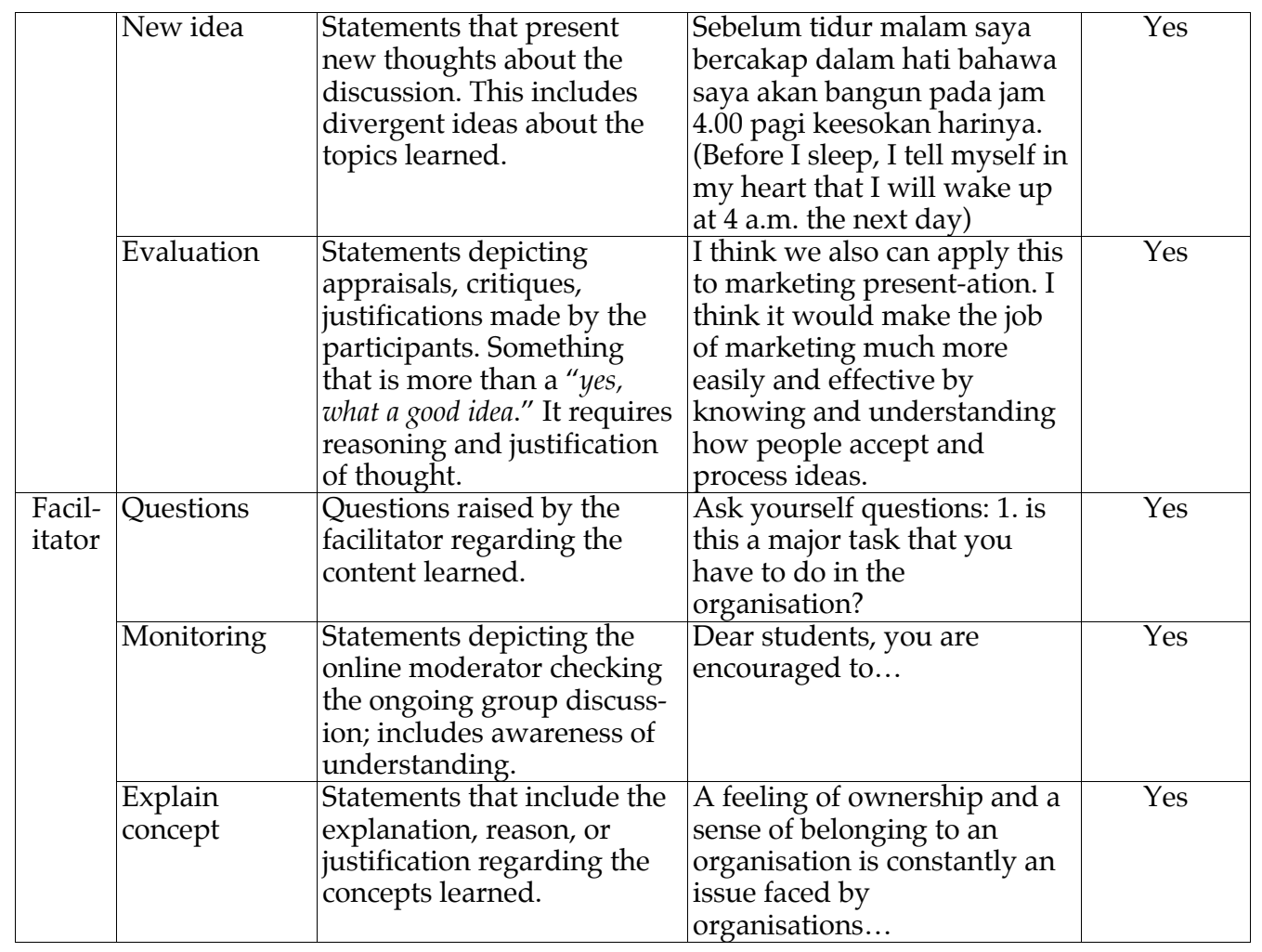

Inter-rater reliability is a critical concern when conducting a content analysis (Wever, Schellens \& Keer, 2006). In this study, two raters coded the data source. One was the second author and the other was a research assistant who was a Masters' degree student at that time. The research assistant was briefed on the coding scheme and trained on how coding was to be carried out. After the training sessions, each rater coded the computer conferences transcripts independently. Transcripts for one of the asynchronous computer conference were used as pilot data. For most cases, an agreement about the final code could be reached. The two raters coded all the transcripts of the six discussion topics. Two formulas were used to ensure the reliability of the data coded. Based on the percent agreement formula (Miles \& Huberman, 1994), the resulting percent of agreement was $75.8 \%$ for the various categories mentioned in Table 2. The Cohen kappa coefficient (Cohen, 1960) was computed to be 0.71 , which was deemed satisfactory (Huck, 2000).

\section{Data collection}

A total of six asynchronous computer conferences were conducted in the course. The participants' postings were captured from the Quickplace server and converted into 
transcripts in Microsoft Word. Each of the computer conferences had a maximum of 18 course participants and the e-learning facilitator. Each asynchronous computer conference had an average of 75.8 units of analysis. The first asynchronous computer conference had 127 units of analysis, the second had 97 units of analysis, the third had 5 units of analysis, the fourth had 80 units of analysis, the fifth had 92 units of analysis, and the sixth had 54 units of analysis.

\section{Results and discussions}

\section{Knowledge construction indicators}

Referring to Table 3, the non-task related postings accounted for $1.5 \%$ of the total units of analyses for the six asynchronous computer conferences, task related posting contributed $87.0 \%$, and the facilitator's discourse was $11.5 \%$. This show that there were more task related postings than non-task related postings. Furthermore, students communicated more than the facilitator. This depicted a learner centered environment where the students' discourse was more than the facilitator's discourse. The top four sub-categories for the task related category were with examples, followed by ask for

Table 3: Summary of the non-task, task related and facilitator postings

\begin{tabular}{|c|c|c|c|c|c|c|c|c|c|}
\hline \multirow{2}{*}{\multicolumn{2}{|c|}{ Asynchronous CC postings }} & \multicolumn{7}{|c|}{ Frequency of unit of analysis } & \multirow{2}{*}{$\begin{array}{l}\text { Knowledge } \\
\text { construction }\end{array}$} \\
\hline & & CC1 & $\mathrm{CC} 2$ & CC3 & $\mathrm{CC} 4$ & CC5 & CC6 & Total & \\
\hline \multirow{5}{*}{$\begin{array}{l}\text { Non- } \\
\text { task } \\
\text { related }\end{array}$} & Planning & 0 & 0 & 0 & 0 & 0 & 0 & 0 & \\
\hline & Technical & 0 & 0 & 0 & 0 & 0 & 0 & 0 & No \\
\hline & Social & 0 & 0 & 0 & 4 & 2 & 1 & 7 & No \\
\hline & Nonsense & 0 & 0 & 0 & 0 & 0 & 0 & 0 & No \\
\hline & Totals & 0 & 0 & 0 & 4 & 2 & 1 & $\begin{array}{c}7 \\
(1.5 \%)\end{array}$ & \\
\hline \multirow{8}{*}{$\begin{array}{l}\text { Task } \\
\text { related }\end{array}$} & Give opinion & 22 & 30 & 0 & 6 & 24 & 4 & 86 & Yes \\
\hline & With examples & 29 & 2 & 0 & 19 & 18 & 40 & 108 & Yes \\
\hline & Knowledge telling & 17 & 10 & 3 & 36 & 16 & 5 & 87 & Yes \\
\hline & $\begin{array}{l}\text { Inaccurate knowledge } \\
\text { telling }\end{array}$ & 1 & 0 & 0 & 1 & 0 & 0 & 2 & Yes \\
\hline & New ideas & 2 & 0 & 0 & 4 & 1 & 1 & 8 & Yes \\
\hline & Evaluation & 3 & 0 & 0 & 1 & 0 & 0 & 4 & Yes \\
\hline & $\begin{array}{l}\text { Ask for opinion or en- } \\
\text { courage participation }\end{array}$ & 39 & 40 & 1 & 3 & 17 & 1 & 101 & Yes \\
\hline & Totals & 113 & 82 & 4 & 70 & 76 & 51 & $\begin{array}{c}396 \\
(87.0 \%)\end{array}$ & \\
\hline \multirow{4}{*}{$\begin{array}{l}\text { Facil- } \\
\text { itator }\end{array}$} & Questions & 4 & 4 & 0 & 1 & 6 & 2 & 17 & Yes \\
\hline & Monitoring & 3 & 5 & 1 & 5 & 6 & 0 & 20 & Yes \\
\hline & Explain concept & 7 & 6 & 0 & 0 & 2 & 0 & 15 & Yes \\
\hline & Totals & 14 & 15 & 1 & 6 & 14 & 2 & $\begin{array}{c}52 \\
(11.5 \%)\end{array}$ & \\
\hline & Totals all postings & 127 & 97 & 5 & 80 & 92 & 54 & 455 & \\
\hline
\end{tabular}

Note: $\mathrm{CC}=$ Computer conference. $\mathrm{CC} 1$ refers to the first asynchronous CC and so forth 
opinion or encourage participation, knowledge telling, and finally give opinion. There were very few new ideas and the peers hardly evaluated each other.

\section{Quality of knowledge construction}

The general overview of the asynchronous computer conference transcripts indicated that usually the same group of participants created the interdependent responses by sharing their ideas and building upon the ideas of others. Only a few participants picked up ideas from their peers and developed it and co-constructed the knowledge learned. The majority of the students did not comment on the postings of others and most of the postings were isolated and not collaborative in nature. Most of them tended to focus on answering the questions raised by the course facilitator rather than affirming, questioning or critiquing the ideas shared by others.

The three sub-categories of with examples, new ideas, and evaluation within the task related category, which was classified as high level knowledge construction, accounted for 120 units of analyses or $26 \%$ of the total units of analyses (refer Table 3). The lower levels of knowledge construction as depicted in the following sub-categories: give opinion, ask for opinion and knowledge telling had 274 units of analyses or $60.2 \%$ of the total units of analyses (refer Table 3). Thus, for this study, the course participants' conference postings were substantially in the lower levels of knowledge construction.

Thus, although the course participants found that the e-learning component of the course was helpful for learning outside class, as they could access the course site after class hours, the quality of their discussion and the level of knowledge construction remain superficial. Generally, this situation was reflective of the present condition of the Malaysian education system. Although the Malaysian school educational philosophy subscribed to the constructivist teaching philosophy, in tandem with development in the Western world, in reality it is still common to have teachercentered classroom environments. Thus, these participants had come from a system that is didactic in its approach and it would seem that they were still not used to critical and creative discussion. These results were consistent with the findings reported by Hong (2002), for a group of postgraduate students enrolled in an elearning statistics course in a Malaysian tertiary institution. Hong (2002) likewise reported that although there were examples of critical thinking, in most instances, the asynchronous discussions focused on low level thinking.

On the other hand, in the Western context, Pena-Shaff and Nicholls (2004), Shellens and Valcke (2005; 2006) and Veerman and Veldhuis-Diermanse (2001) found that collaborative asynchronous discussions in their studies were task oriented and there were high phases of knowledge constructions.

\section{Suggestions for improving the quality of knowledge construction}

Therefore, as suggested in Hong (2002), the findings in the present study indicated a need for a generic course on critical thinking to be conducted during the initial stages 
of Masters degree programs at Malaysian tertiary education institutions. Furthermore, although lurking was not investigated in this study, it has been found to be common in most asynchronous computer conferencing (Rovai, 2000). Course designs on blended learning should include the asynchronous computer conferences as a graded element of the course, to encourage active participation. Yet this appears to be inadequate in the present study, as although the students were informed that their participation in asynchronous computer conferences would be graded, many of them sent brief messages without elaborations, which were in the give opinion, ask for opinion and knowledge telling sub-categories.

A study conducted by Rovai (2000) showed that an e-learning facilitator need not reply to all of the postings made by students. What is important is the feeling by contributors that their work is read by others. Rovai added that the facilitator should have a good sense of timing about when immediate feedback should be provided. This calls for further research on when the facilitator should reply to students and how a reply should be made, to improve the quality discussions in asynchronous computer conferencing.

Many of the students attempted to answer the questions rather than to debate or question the postings made by their peers or the facilitator. This bring into focus the need to expose students to good questioning practices, especially those that can develop students' thinking and reasoning skills (Barrows, 1992).

Furthermore, Ewing and Miller (2002) suggest that learners must shoulder individual responsibility and accountability during asynchronous computer conferencing. This view is congruent with the argument made by Slavin (as cited in Rovai, 2000), a proponent of collaborative learning, that group goals and individual accountability should also be implemented as a climate setting process prior to the asynchronous computer conferencing activities.

\section{Limitations of the study}

The limitations of this study, such as the sample size and the duration of study. limited the extent to which they may be generalised. This study was presented to promote deeper and further discussion about knowledge construction in blended learning environments.

\section{Conclusions}

The findings from this study indicate that adult postgraduate students could benefit from training and degree programs incorporating blended learning environments with asynchronous computer conferences, as a means for them to keep in touch with each other beyond the walls of the class, anytime, anyplace thus realising a self directed learning experience. 
Discourse analyses showed that the learning environment was learner centered, but the quality of knowledge construction can be improved. Low level knowledge construction postings were a substantial proportion, pointing to the need for the facilitator to encourage the students to go beyond regurgitating of facts. Several ways are suggested to encourage higher order thinking discussions. More guidance should be given to the students to refrain from merely knowledge telling. The e-learning facilitator could model the dynamics of sharing information and transforming knowledge learned. Learner centered structures and explicit training or climate setting sessions should also be implemented to help the participants to critically analyse and synthesise the knowledge they have learned.

From the discussions above, although research in the Western context has shown that there are possibilities for quality knowledge construction in asynchronous computer conferencing, it is not easily attainable, especially in Eastern cultures. There is a need for future research on how various other variables influence high quality knowledge construction. These include course design, the critical thinking skills that students possess, and when and how feedback can influence the quality of knowledge construction of learners in asynchronous computer conferencing for a blended learning environment.

\section{Acknowledgements}

This work was supported by Universiti Malaysia Sarawak (UNIMAS) under a Fundamental Research Grant 03(27)/394/2003(131)

\section{References}

Allan, M. (2004). A peek into the life of online learning discussion forums: Implications for Webbased distance learning. International Review of Research in Open and Distance Learning, 5(2). http: / / www.irrodl.org/index.php/irrodl/article/view/188/270

Barrows, H.S. (1992). The tutorial process. Springfield, IL: Southern Illinois University School of Medicine.

Blanchette, J. (2001). Questions in the online learning environment. Journal of Distance Education, 16(2). http:/ / cade.icaap.org/vol16.2/ blanchette.html

Cohen, J. (1960). A coefficient of agreement for nominal scales. Educational and Psychological Measurement, 20(1), 37-46.

Egan, C., Jefferies, A. \& Johal, J. (2006). Providing fine-grained feedback within an on-line learning system - Identifying the workers from the lurkers and the shirkers. The Electronic Journal of e-Learning, 4(1), 15-24. http:/ / www.ejel.org/volume-4/v4-i1/ egan-colin-et-al.pdf

Elbow, P. (1994). Writing for learning - not just for demonstrating learning. University of Massachusetts, Amherst. 
Ewing, J. \& Miller, D. (2002). A framework for evaluating computer supported collaborative learning. Educational Technology \& Society, 5(1), 112-118. http:/ / www.ifets.info/journals/5_1/ewing.html

Frank, M., Kurtz, G. \& Levin, N. (2002). Implications of presenting pre-university courses using the blended e-learning approach. Educational Technology E Society, 5(4), 137-147. http:/ / www.ifets.info/journals/5_4/frank.html

Frey, B.A., Millie, S.S. \& Alman, S.W. (2006). Mapping MLIS asynchronous discussions. International Journal of Instructional Technology and Distance Learning, 3(1). http:/ /itdl.org/Journal/jan_06/article01.htm

Garrison, D.R., Anderson, T. \& Archer, W. (2001). Critical thinking, cognitive presence, and computer conferencing in distance education. The American Journal of Distance Education, 15(1), 7-23.

Gee, J.P. (1999). An introduction to discourse analysis: Theory and method. London: Taylor \& Francis.

Ginns, P. \& Ellis, R. (2007). Quality in blended learning: Exploring the relationships between online and face-to-face teaching and learning. The Internet and Higher Education, 10(1), 53-64.

HEFCE (2005). E-learning strategy and capital investment funding. [viewed 10 Sep 2005, verified 14 Jan 2008] http: / / www.hefce.ac.uk/pubs/circlets/2005/cl05_05/

Hmelo-Silver, C.E. (2003). Analyzing collaborative knowledge construction: multiple methods for integrated understanding. Computers E Education, 41(3), 397-420.

Hong, K.S., Lee, A.C. \& Liau, T.L. (2005). Effects of system's and user's characteristics on elearning use: A study at Universiti Malaysia Sarawak. Journal of Science and Mathematics Education in Southeast Asia, 28(2), 1-25.

Hong, K.S. (2002). Evaluation of a Web-based tertiary statistics course using a problem-based learning approach. Unpublished PhD Thesis, University of Otago, New Zealand.

Huck, S.W. (2000). Research statistics and research. New York: Addison Wesley Longman.

Hunkins, F.P. (1972). Questioning strategies and techniques. Boston, MA: Allyn \& Bacon, Inc.

Jonassen, D.H. (2001). Computers as mindtools for schools: Engaging critical thinking. Upper Saddle River, New Jersey: Prentice Hall.

King, K.P. (2002). Identifying success in online teacher education and professional development. The Internet and Higher Education, 5(3), 231-246.

Mazzolini, M. \& Maddison, S. (2003). Sage, guide or ghost? The effect of instructor intervention on student participation in online discussion forums. Computers $\mathcal{E}$ Education, 40(3), 237-253.

Meyer, K.A. (2004). Evaluating online discussions: Four different frames of analysis. Journal of Asynchronous Learning Networks, 8(2). http: / / www.sloan-c.org/publications/jaln/v8n2/v8n2_meyer.asp

Miles, M.B. \& Huberman, A.M. (1994). Qualitative data analysis: An expanded sourcebook (2nd ed.). Thousand Oaks, CA: Sage Publications. 
Monroe, B. (2003). Fostering critical engagement in online discussion: The Washington State University Study. Pullman, WA: Washington Center for Improving the Quality of Undergraduate Education, Washington State University. [verified 14 Jan 2008] http:/ /ittar.wikispaces.com/ space/showimage/Fostering_Critical_Engagement_in_Online_Discussions_by_Barbara_Monroe.pdf

Muilenburg, L. \& Berge, Z. (2000). A framework for designing questions for online learning. eModerators [viewed 22 Sep 2003, verified 14 Jan 2008]

http: / / www.emoderators.com/moderators / muilenburg.html

Oliver, M. \& Trigwell, K. (2005). Can 'blended learning' be redeemed? E-Learning, 2(1). [viewed 15 Dec 2006, verified 14 Jan 2008] http: / / www.wwwords.co.uk/pdf/viewpdf.asp? j=elea\&vol=2\&issue=1\&year=2005\&article=3_Oliver_ELEA_2_1_web\&id=124.182.50.158

Palloff, R.M. \& Pratt, K. (2002). What we know about electronic learning. In L. Foster, B.L. Bower \& L.W. Watson (Eds.), ASHE reader distance education: Teaching and learning in higher education. Boston, MA: Pearson Custom Publishing.

Pena-Shaff, J.B. \& Nicholls, C. (2004). Analyzing student interactions and meaning construction in computer bulletin board discussions. Computers $\mathcal{E}$ Education, 42(3), 243-265

Reasons, S.G., Valadares, K. \& Slavkin, M. (2005). Questioning the hybrid model: Student outcomes in the different course formats. Journal of Asynchronous Learning Networks, 9(1). http:/ / www.sloan-c.org/publications/jaln/v9n1/v9n1_reasons.asp

Rourke, L. \& Anderson, T. (2004). Validity in quantitative content analysis. Educational Technology Research and Development, 52(1), 5-18.

Rovai, A.P. (2000). Building and sustaining community in asynchronous learning networks. The Internet and Higher Education, 3(4), 285-297.

Rovai, A.P. (2004). A constructivist approach to online college learning. The Internet and Higher Education, 7(2), 79-93.

Schellens, T. \& Valcke, M. (2005). Collaborative learning in asynchronous discussion groups: What about the impact on cognitive processing? Computers in Human Behavior, 21(6), 957-975.

Schellens, T. \& Valcke, M. (2006). Fostering knowledge construction in university students through asynchronous discussion groups. Computers E Education, 46(1), 349-370.

Smythe, K. \& Halonen, J. (undated). Using the new Bloom's taxonomy to design meaningful learning assessments. The Assessment CyberGuide for Learning Goals and Outcomes in the Undergraduate Psychology Major. American Psychological Association. http://www.apa.org/ed/new_blooms.html

Universiti Malaysia Sarawak (2002). eLearning @ UNIMAS: The White Paper. Unpublished manuscript. Kota Samarahan, Sarawak: CALM, Universiti Malaysia Sarawak.

Veerman, A. \& Veldhuis-Diermanse, E. (2001). Collaborative learning through computermediated communication in academic education. In P. Dillenbourg, A. Eurelings \& K. Hakkarainen (Eds.), European perspectives on computer-supported collaborative learning. Proceedings of the First European Conferenceon CSCL. Maastricht: McLuhan Institute, University of Maastricht. [verified 14 Jan 2008] http: / / www.ll.unimaas.nl/euro-cscl/Papers/166.doc 
Walker, G. (2005). Critical thinking in asynchronous discussions. International Journal of Instructional Technology and Distance Learning, 6(2). [viewed 12 Dec 2006, verified 14 Jan 2008] http: / / itdl.org/Journal/Jun_05/article02.htm

Wever, D. B., Schellens, M.V. \& Keer, H.V. (2006). Content analysis scheme to analyze transcripts of online asynchronous discussion groups: A review. Computers $\mathcal{E}$ Education, 46(1), 6-28.

Woo, Y. \& Reeves, T.C. (2007). Meaningful interaction in web-based learning: A social constructivist interpretation. The Internet and Higher Education, 10(1), 15-25.

Wu, D. \& Hiltz, S.R. (2004). Predicting learning from asynchronous online discussions. Journal of Asynchronous Learning Networks, 8(2), 131-152. http:/ / www.sloanc.org/publications/jaln/v8n2/v8n2_wu.asp

Young, A. \& Norgard, C. (2006). Assessing the quality of online courses from the students' perspective. The Internet and Higher Education, 9(2), 107-115.

Associate Professor Hong Kian Sam and Ms Julia Ai Cheng Lee Faculty of Cognitive Sciences and Human Development

Universiti Malaysia Sarawak, 94300 Kota Samarahan, Sarawak, Malaysia

Email: hksam@fcs.unimas.my, aclee@calm.unimas.my 